\title{
Quality of Life and Knowledge Among Elderly Patients with Chronic Hepatitis at Assiut City
}

\author{
Sanaa I. Elmahdy ${ }^{1}$ Neama M. EL-magrbi ${ }^{2}$ Asmaa K. Hassan $^{3}$. \\ Clinical Nurse Specialist at the Unit of Treatment of Viral Hepatitis, Ministry of Health, Assiut. \\ Assistant Professor of Community Health Nursing, Faculty of Nursing, Assiut University. \\ Lecturer of Community Health Nursing, Faculty of Nursing, Assiut University.
}

\begin{abstract}
Background: Chronic hepatitis is typically silent; signs and symptoms that present only in those with advanced disease. The study aimed to: assess the quality of life and knowledge about the elderly patients with chronic hepatitis at Assiut city. Patients and method: descriptive design was used in this study. It was conducted at two Geriatric Homes, two Geriatric Social Clubs and Unit of Treatment for Viral Hepatitis. A convenient sample (300) elderly participant divided into group 1 (150) and group 2 (150). Two tools were used: 1 . Structure interview questionnaire, 2. Chronic liver disease questionnaire. Results: It clarifies that $69.3 \%$ of group1 were males, versus $47.3 \%$ in group 2 . And $8.7 \%$ of the group1 has university, while $24.7 \%$ from group2. According to marital status $58.7 \% \& 50.7 \%$ respectively of the group 1 and group 2 are married. And show negative correlations between score of knowledge with "Emotional Function" and "Worry". The study concluded Negative correlation between grade of knowledge and quality of life domains in group1. It recommends providing educational programs to improve elderly knowledge about chronic hepatitis and early detection especially high risk group.
\end{abstract}

\section{Keywords: Chronic Hepatitis \& Quality of Life.}

\section{Introduction}

Chronic Liver Disease (CLD) represents significant morbidity and mortality (Rahimi \& Rockey, 2011). That causes of illnesses and changes in many aspects of life not only the individual but also their family and affects society (Pashaee et al., 2010).

Chronic liver disease that cause negatively impacts Health-Related Quality of Life (HRQL) with patients suffering from fatigue, anxiety, depression, loss of self-esteem, inability to function at work, and emotional problems that decrease quality of life (Lam et al., 2009).

Half of patients with Chronic liver disease have symptoms that cause them to seek medical care (Ware \& Sherbourne, 2009). Stated of Chronic Hepatitis is affected not only physically but also psychologically, socially, and economically. That required Major adjustments to make lifestyle changes, provide information regarding community support programs (Hamza et al., 2015).

Liver disease are categorized into more hundred types out of which alcoholic liver disease, nonalcoholic fatty liver disease, viral hepatitis, fibrosis, cirrhosis and liver cancer are commonly prevalent. Presence of liver disease is steadily increasing over the years. It has been ranked as the fifth most common causes of death by national statistics (Singh \& Pandey, 2014)

Chronic liver disease is defined by the presence of tissue damage that impairs the organ's ability to carry out its usual functions. The process takes place over time and begins with fatty changes; these are reversible if identified early on and appropriate action, such as losing weight and/or abstinence from alcohol, is taken. If the early changes are not identified then the fatty changes will develop into inflammatory changes. This inflammation leads to steatohepatitis, which in non-alcoholic liver disease is known as - Non-Alcoholic Steato-Hepatitis (NASH). The next stage is liver fibrosis and, finally, cirrhosis (Scottish Public Health Observatory Report on Chronic Liver Disease, 2012).

The theme for this year's World Hepatitis Day is "Prevent hepatitis. Act now". Viral hepatitis is caused by 5 distinct hepatitis viruses. Infection from these viruses results in approximately 1.45 million deaths each year, Worldwide 400 million people are living with hepatitis B or C, Hepatitis causes $80 \%$ of liver cancer deaths (WHO, 2015).

Three causes of chronic liver disease are: alcohol, viral infections and obesity. The prevalence of chronic liver disease is affected by demographics such as age, ethnicity, religion and deprivation factors (Dooley, 2011).

Nurses in all areas of practice should be able to offer health information and education to patients and his her family to raise awareness of liver disease and promote healthy-living strategies. Nurses need to develop their knowledge and skills in caring for people who have advanced liver disease to decrease prevalence of mortality and morbidity associated with chronic liver disease and cirrhosis. The Royal College of Nursing (RCN) has developed a 
competency framework for caring for people with liver disease (Clements \& Greenslade, 2013).

\section{Significance of the study}

Chronic liver diseases in particular are increasingly widespread, that considered a global public health problem (WHO, 2012). That substantially contributes to mortality and morbidity rates (Mühlberger et al., 2009).

Egypt is the country with highest HCV prevalence in the world; in 2008 the Egyptian Demographic Health Survey, most people aged >59 that birth between 1960-1980 which is largely attributable in this phenomena that will be seen in most countries as the bulk of worldwide HCV infections during the mass schistosomaisis treatment campaigns (Kandeel etal., 2015).

\section{Aim of the study}

This study is aimed to assess the quality of life and knowledge about chronic hepatitis among elderly patients with chronic hepatitis at Assiut city.

\section{Research question}

- Does chronic hepatitis affects the quality of life among elderly patients?

- What is the level of knowledge of elderly patients about chronic hepatitis?

\section{Patients \& method}

Research design:

A descriptive research design (comparison between two groups) was used in this study.

\section{Setting}

This study was conducted in Assiut City which divided into: two Geriatric Homes, two Geriatric Social Clubs and Unit of Treatment for Viral Hepatitis.

\section{Sample}

A purposive sample was used to include all geriatric people at the following table. The total sample was 300 divided into:

\begin{tabular}{|c|l|c|}
\hline Items & \multicolumn{1}{|c|}{ Name of place } & Number \\
\hline \multirow{4}{*}{$\begin{array}{c}\text { Geriatric } \\
\text { Homes }\end{array}$} & $\begin{array}{l}\text { Dar Belal } \\
\text { Ebn-Rabah }\end{array}$ & 15 \\
\cline { 2 - 3 } & $\begin{array}{l}\text { Dar El-mosenen in } \\
\text { El-Markaz El- } \\
\end{array}$ & 5 \\
\hline \multirow{3}{*}{$\begin{array}{l}\text { Sakafy Al-Eslamy } \\
\text { Seriatric } \\
\text { Social } \\
\text { Clubs }\end{array}$} & $\begin{array}{l}\text { El-gamaya } \\
\text { El-sharaya }\end{array}$ & \multirow{2}{*}{130} \\
\cline { 2 - 3 } & $\begin{array}{l}\text { El-markaz } \\
\text { El-sakafy } \\
\text { Al-eslamy }\end{array}$ & \\
\hline
\end{tabular}

\begin{tabular}{|l|l|l|}
\hline Unit of & \multicolumn{2}{|l|}{ Therapeutic Unit } \\
Treatment & of Viral Hepatitis & 150 \\
for Viral & affiliated to & \\
Hepatitis & $\begin{array}{l}\text { Directorater of } \\
\text { Health Affairs at }\end{array}$ & \\
& $\begin{array}{l}\text { Assiut City } \\
\text { (outpatient) }\end{array}$ & \\
\hline Total & & 300 \\
\hline
\end{tabular}

Group1 consist of followings criteria

- All elderly patients diagnosed with chronic liver disease aged 60 years and above, who can be communicated, and accept participation in the study.

Group2 consist of followings criteria

- All elderly participants free from chronic liver diseases that are at the same age group as the cases.

C-Tools of the study:-

Two tools were used to collect data for this study:-

Tool (I): Interview Questionnaire Sheet

Structured questionnaire sheet was developed by investigator to collect information from the studied subject was included three parts:-

Part 1: personal characteristics of studied subject This include: name, age, sex, education level, marital status, residence, living with, current work status.

part 2: knowledge of studied subject about Nutritional habits, food elements and drinking habits:

It included the following questions: Special diet, type of diet, Feeding system changed with age , Number of basic meals, eat Almspkat, carbohydrates, legumes, grilled fish, red meat, White meat..ect.

Part 3: assessment knowledge of studied subject about chronic hepatitis and history of disease for group1

It included the following questions: definition of chronic hepatitis, Source of this information, Mode of transmission, Signs and Symptoms, Complications, Treatment, cure rate, method of disease detection, regular follow-up since diagnosis, regularity of follow-up, place of follow-up, prohibited drugs for hepatitis patients.

Scoring system

The total percentage score of knowledge was summed-up and then converted into percent score knowledge was considered categorized as poor , $(<50 \%)$, satisfactory $(50-75 \%)$ and good $>75 \%$ (Hamza et al., 2015).

second tools: Questionnaire to Measure the Quality of Life

The quality of life questionnaire developed by Hamza et al., (2015) it included 22 items in the following domains: abdominal symptoms, fatigue, systemic symptoms, activity, emotional function and worry. The response of quality of life questionnaire 
results in $0-2$ scales: $0=$ "all of the time", $1=$ " little of the time" and 2="none of the time". The quality of life questionnaire was shown to have constructed validity from the studies in CLD (Hamza et al., 2015). Each domain including items: Abdominal symptoms domain including 2 items; Fatigue symptoms domain including 5 items; Systematic symptoms domain including 5 items; Activity symptoms domain including 3 items; Emotional function domain including 5 items; Warry domain including 2 items.

\section{Scoring system}

The grade for each item were summed to create a total score 22-44 from worst to beast Quality Of Life (QOL), Type of answers ranging from "all of the time", "little of the time" and "none of the time" $(0,1,2)$ grades. The total percentage grade was categorized as mild impairment if quality of life $(<50 \%)$, moderate impairment $(50-75 \%)$ and severe impairment if the patient got a score $>75 \%$ (Alghazaly et al., 2016).

\section{Methodology}

Administrative phase

An official letter of approval which was obtained from the Dean of Faculty of Nursing- Assiut University was sent to directors of Unit of Viral Hepatitis Treatment, Geriatric Homes and Geriatric Clubs at Assiut City to carry research in the selected places. That letter included explanation the purpose and nature of the research and permission to collect the necessary data.

\section{Content validity of tools}

The tools were tested for content validity by jury of 5 experts in the field of community health care nursing and Tropical Medicine and Gastroenterology at Assuit University and the necessary modifications were done.

\section{Reliability}

was estimated by Cronbach's Alpha for tool 1 Interview Questionnaire sheet and its result was 0.79, for tool 2 Chronic Liver Disease Questionnaire to Measure the Quality of Life and its result was0.87which were accepted.

\section{Pilot Study}

A pilot study was carried out before starting of data on $10 \%$ about (30) elderly participant. Its purpose is to assess the feasibility of the research and clarity of the data collection tools. It also helped to estimate the time needed for filling the forms. The studied subjects were included on the actual study.

\section{Data collection Phase}

\section{Ethical consideration}

Written consent taken from director of the place and oral consent should be taken from all members of elderly who participate in the study. The purpose of the study was explained for the director and every interviewed elderly member.

\section{Field Works}

The studied subject fulfilling the research criteria was renormalized assigned into two groups (group1 and group2). Data was collected in the period from first day of May to end of August 2015; about 6-7 participant through three days weekly. The purpose of the study was explained to the participants prior for answering the question:-

- Group (1): was collected from Unit of Viral Hepatitis of treatment; the study was carried out during morning for all available participants, the interview sheet was filled out individualized with the participants and was distributed to be answered within (20 minutes) or more depending on the participant response to a question then collected.

- Group (2): was collected from geriatric homes and geriatric clubs in Assiut city; the study was carried out during night for all available participants, the interview and individualized sheet with the participants and was distributed to be answered within (20 minutes) or more depending on the participant response to a question then collected.

\section{Statistical Analysis}

- The data obtained were reviewed, prepared for computer entry, coded, analyzed and tabulated. Descriptive statistics (i.e., frequencies, percentage, mean standard deviation, etc.) was done by using software package for statistical science (SPSS) Version 11. Chi-square test and correlation was used to compare differences in the distribution of frequencies among different groups, it is considered significant when $\mathrm{P}<0.05$. 


\section{Results}

Table (1): Distribution of studied subject regarding to their Personal characteristics in Assiut City 2015.

\begin{tabular}{|c|c|c|c|c|c|}
\hline \multirow[t]{2}{*}{ Items } & \multicolumn{2}{|c|}{$\begin{array}{l}\text { Group } 1 \\
(n=150)\end{array}$} & \multicolumn{2}{|c|}{$\begin{array}{l}\text { Group } 2 \\
(n=150)\end{array}$} & \multirow[t]{2}{*}{ P-value } \\
\hline & No. & $\%$ & No. & $\%$ & \\
\hline \multicolumn{5}{|l|}{ Sex } & \multirow{3}{*}{$0.000 *$} \\
\hline Male & 104 & 69.3 & 71 & 47.3 & \\
\hline Female & 46 & 30.7 & 79 & 52.7 & \\
\hline \multicolumn{5}{|l|}{ Age: } & \multirow{4}{*}{0.098} \\
\hline 60 years & 101 & 67.4 & 89 & 59.3 & \\
\hline $65-70$ years & 41 & 27.3 & 43 & 28.7 & \\
\hline$>70$ years & 8 & 5.3 & 18 & 12.0 & \\
\hline Mean \pm SD & \multicolumn{2}{|c|}{$63.63 \pm 3.49$} & \multicolumn{2}{|c|}{$64.40 \pm 4.46$} & 0.096 \\
\hline \multicolumn{5}{|l|}{ Educational level } & \multirow{7}{*}{$0.004 *$} \\
\hline Illiterate & 30 & 20.0 & 21 & 14.0 & \\
\hline Read \& write & 28 & 18.7 & 15 & 10.0 & \\
\hline Primary & 16 & 10.7 & 18 & 12.0 & \\
\hline Preparatory & 25 & 16.6 & 22 & 14.6 & \\
\hline Secondary & 38 & 25.3 & 37 & 24.7 & \\
\hline University & 13 & 8.7 & 37 & 24.7 & \\
\hline \multicolumn{5}{|l|}{ Marital status } & \multirow{4}{*}{0.229} \\
\hline Single & 5 & 3.3 & 10 & 6.7 & \\
\hline Married & 88 & 58.7 & 76 & 50.7 & \\
\hline Divorced/ widow & 57 & 38.0 & 64 & 42.6 & \\
\hline \multicolumn{5}{|l|}{ Residence } & \multirow{3}{*}{$0.000 *$} \\
\hline Rural & 95 & 63.3 & 28 & 18.7 & \\
\hline Urban & 55 & 36.7 & 122 & 81.3 & \\
\hline \multicolumn{5}{|l|}{ Living with } & \multirow{4}{*}{$0.000 *$} \\
\hline Alone & 13 & 8.7 & 34 & 22.7 & \\
\hline With family & 137 & 91.3 & 108 & 72.0 & \\
\hline Elderly home & 0 & 0.0 & 8 & 5.3 & \\
\hline \multicolumn{5}{|l|}{ Current work status } & \multirow{3}{*}{0.329} \\
\hline Working & 12 & 8.0 & 17 & 11.3 & \\
\hline Not working & 138 & 92.0 & 133 & 88.7 & \\
\hline
\end{tabular}

Table (2): Correlation between total score of knowledge and quality of life of studied subject for group1 at Assiut City 2015.

\begin{tabular}{|l|c|c|}
\hline \multirow{2}{*}{} & \multicolumn{2}{|c|}{ Knowledge score $\mathbf{n = 1 5 0}$} \\
\cline { 2 - 3 } & r-value & P-value \\
\hline Abdominal symptoms & -0.013 & 0.878 \\
\hline Fatigue & -0.037 & 0.656 \\
\hline Systematic symptoms & -0.054 & 0.509 \\
\hline Activity & -0.105 & 0.201 \\
\hline Emotional function & $\mathbf{- 0 . 1 9 2}$ & $\mathbf{0 . 0 1 9}$ \\
\hline Worry & $\mathbf{- 0 . 1 8 9}$ & $\mathbf{0 . 0 2 1}$ \\
\hline Quality of life domains & -0.147 & 0.073 \\
\hline
\end{tabular}


Table (3): Relation between total score of knowledge about chronic hepatitis among group 1 and personal characteristics in Assiut City 2015 (No: 150).

\begin{tabular}{|c|c|c|c|c|c|c|c|}
\hline \multirow{3}{*}{ Items } & \multicolumn{6}{|c|}{ score of knowledge } & \multirow{3}{*}{$\begin{array}{l}P \text { - } \\
\text { value }\end{array}$} \\
\hline & \multicolumn{2}{|c|}{$\begin{array}{c}\text { Poor } \\
(n=49)\end{array}$} & \multicolumn{2}{|c|}{$\begin{array}{c}\text { Satisfactory } \\
(n=79)\end{array}$} & \multicolumn{2}{|c|}{$\begin{array}{c}\text { Good } \\
(n=22)\end{array}$} & \\
\hline & No. & $\%$ & No. & $\%$ & No. & $\%$ & \\
\hline \multicolumn{7}{|l|}{ Sex } & \multirow{3}{*}{0.532} \\
\hline Male & 31 & 63.3 & 57 & 72.2 & 16 & 72.7 & \\
\hline Female & 18 & 36.7 & 22 & 27.8 & 6 & 27.3 & \\
\hline \multicolumn{7}{|l|}{ Age } & \multirow{4}{*}{0.393} \\
\hline$<65$ years & 28 & 57.1 & 56 & 70.9 & 17 & 77.3 & \\
\hline $65-70$ years & 17 & 34.7 & 20 & 25.3 & 4 & 18.2 & \\
\hline$>70$ years & 4 & 8.2 & 3 & 3.8 & 1 & 4.5 & \\
\hline \multicolumn{7}{|l|}{ Educational level } & \multirow{4}{*}{$0.000 *$} \\
\hline Illiterate/ Read \& write & 30 & 61.2 & 27 & 34.2 & 1 & 4.5 & \\
\hline Basic education & 13 & 26.5 & 22 & 27.8 & 6 & 27.3 & \\
\hline Secondary/ University & 6 & 12.3 & 30 & 38.0 & 15 & 68.2 & \\
\hline \multicolumn{7}{|l|}{ Residence } & \multirow{3}{*}{0.168} \\
\hline Rural & 33 & 67.3 & 45 & 57.0 & 17 & 77.3 & \\
\hline Urban & 16 & 32.7 & 34 & 43.0 & 5 & 22.7 & \\
\hline \multicolumn{7}{|l|}{ Current work status } & \multirow{3}{*}{0.462} \\
\hline Working & 2 & 4.1 & 8 & 10.1 & 2 & 9.1 & \\
\hline Not working & 47 & 95.9 & 71 & 89.9 & 20 & 90.9 & \\
\hline
\end{tabular}

Table (4): Relation between total score of knowledge about chronic hepatitis among group 2 and personal characteristics in Assiut City 2015(No: 150).

\begin{tabular}{|c|c|c|c|c|c|c|c|}
\hline \multirow{3}{*}{ Items } & \multicolumn{6}{|c|}{ score of knowledge } & \multirow{3}{*}{$\begin{array}{c}\text { P- } \\
\text { value }\end{array}$} \\
\hline & \multicolumn{2}{|c|}{$\begin{array}{c}\text { Poor } \\
(n=111)\end{array}$} & \multicolumn{2}{|c|}{$\begin{array}{c}\text { Satisfactory } \\
(n=35)\end{array}$} & \multicolumn{2}{|c|}{$\begin{array}{l}\text { Good } \\
(n=4)\end{array}$} & \\
\hline & No. & $\%$ & No. & $\%$ & No. & $\%$ & \\
\hline \multicolumn{7}{|l|}{$\overline{\text { Sex }}$} & \multirow{3}{*}{0.593} \\
\hline Male & 52 & 46.8 & 18 & 51.4 & 1 & 25.0 & \\
\hline Female & 59 & 53.2 & 17 & 48.6 & 3 & 75.0 & \\
\hline \multicolumn{7}{|l|}{$\overline{\text { Age }}$} & \multirow{4}{*}{0.293} \\
\hline$<65$ years & 62 & 55.9 & 23 & 65.7 & 4 & 100.0 & \\
\hline $65-70$ years & 33 & 29.7 & 10 & 28.6 & 0 & 0.0 & \\
\hline$>70$ years & 16 & 14.4 & 2 & 5.7 & 0 & 0.0 & \\
\hline \multicolumn{7}{|l|}{ Educational level } & \multirow{4}{*}{0.154} \\
\hline Illiterate/ Read \& write & 30 & 27.0 & 6 & 17.1 & 0 & 0.0 & \\
\hline Basic education & 24 & 21.6 & 14 & 40.0 & 2 & 50.0 & \\
\hline Secondary/ University & 57 & 51.4 & 15 & 42.9 & 2 & 50.0 & \\
\hline \multicolumn{7}{|l|}{ Residence } & \multirow{3}{*}{0.444} \\
\hline Rural & 23 & 20.7 & 4 & 11.4 & 1 & 25.0 & \\
\hline Urban & 88 & 79.3 & 31 & 88.6 & 3 & 75.0 & \\
\hline \multicolumn{7}{|l|}{ Current work status } & \multirow{3}{*}{0.131} \\
\hline Working & 16 & 14.4 & 1 & 2.9 & 0 & 0.0 & \\
\hline Not working & 95 & 85.6 & 34 & 97.1 & 4 & 100.0 & \\
\hline \multicolumn{7}{|l|}{ Regular income } & \multirow{3}{*}{0.351} \\
\hline Yes & 82 & 73.9 & 30 & 85.7 & 3 & 75.0 & \\
\hline No & 29 & 26.1 & 5 & 14.3 & 1 & 25.0 & \\
\hline
\end{tabular}




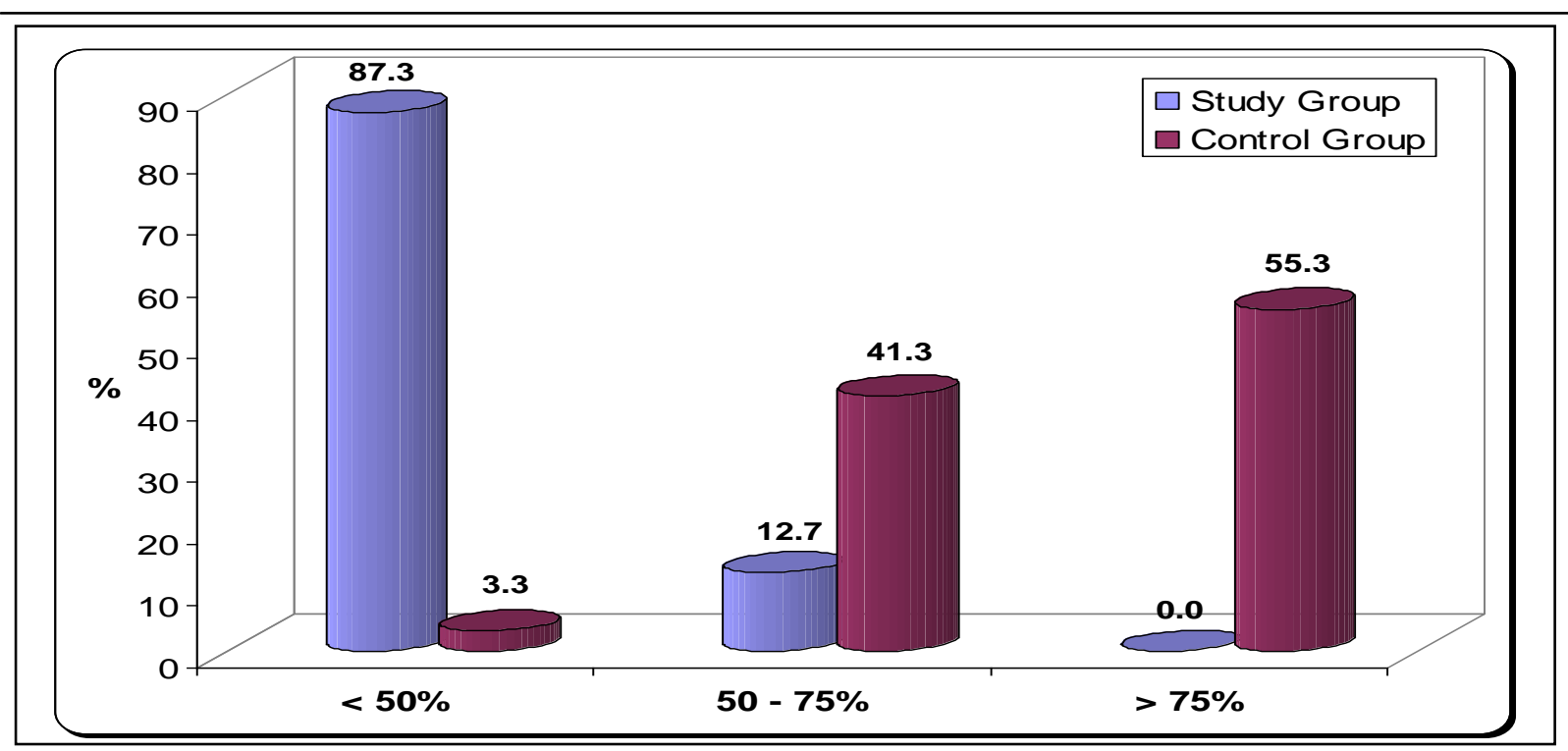

Mild impairment $\quad$ Moderate impairment Sever impairment

Figure (1): Total scoring of studied subject regarding quality of life according to scoring system in Assiut City 2015.

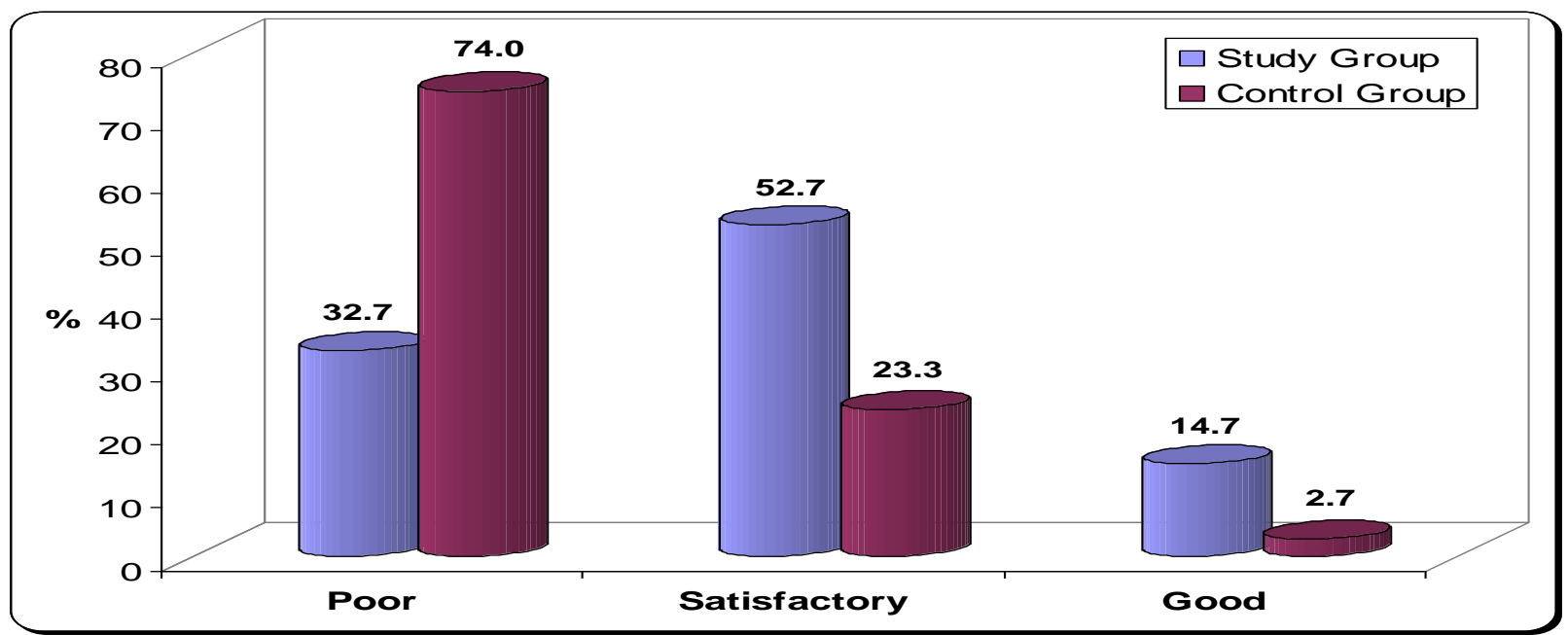

Figure (2): Total score of knowledge of studied subject regarding chronic hepatitis in Assiut City 2015.

Table (1): Distribution of the studied subject regarding to personal characteristics at Assiut City. It clarifies that $69.3 \%$ of group1 were males, versus $47.3 \%$ in group 2 . And $8.7 \%$ of group 1 has university, while $24.7 \%$ from group2. According to residence $63.3 \%$ of group1was from rural, while $18.7 \%$ in group 2 were from rural areas. While, majority $91.3 \%$ of group1 was living with their family versus $72 \%$ of group2.

Table (2): Illustrates correlation between score of knowledge and quality of life domains. It shows that there were significant negative correlations between score of knowledge with "Emotional Function" and "Worry".

Table (3): Reveals that relation between personal characteristics in group 1 and levels of knowledge about chronic hepatitis. It shows statistical significant difference between score of knowledge of studied group about chronic hepatitis and their educational level at $\mathrm{p}$-value (0.000).

Table (4): Shows relation between personal characteristics in group 2 and score of knowledge about chronic hepatitis. It shows that there are no statistical significant differences between score of knowledge about chronic hepatitis and all items of personal characteristics in group 2.

Figure (1): Shows that, regarding group (1) $87.3 \%$ of those who $<50 \%$ in quality of life score, while $3.3 \%$ of group (2) who $<50 \%$. That high statistically significant difference at value $(\mathrm{P}=0.000)$.

Figure (2): Regarding group 1 more than half $(52.7 \%)$ had satisfactory knowledge score, while less 
than one quarter (23.3\%) of group 2. Also had satisfactory score of statistically significant difference at value $(\mathrm{P}=0.000)$.

\section{Discussion}

Liver disease is a serious public health problem that affects patient's quality of life (QoL). The measure of health related qualities of life (HRQoL) are increasingly recognized as important tools for assessing disease outcomes and determining health interventions (Matsushita, 2014).

The quality of life questionnaire is specific instrument for assessment Health related quality of life in patients with chronic liver disease (CLD). It is reliable, valid, reproducible, short, easy to administer and economic, which is validated and cross culturally adapted into many different languages (Dusan, 2013).

Despite the many studies that have shown a reduced related quality of life in hepatology. The results of the present study showed that more than two third of group1 were male followed by slightly less than half of studied participants were female. Also slightly more than quarter of the group 1 has secondary educated, while slightly less than quarter of the group 2. According to residence less than two third of group1had in rural, while less than fifth in group2. Majority of group1 living with family versus less than three quarter of group2.

This result was in line Gao et al., (2013) in study about "Health-related quality of life in Chinese patients with chronic liver disease" who noticed quality of life scores decreased with advancing age; thus, health related quality of life also decreased with age.

This was disagreement with study by Alghazaly et al., (2016) about "Impact of chronic liver disease on Health Related Quality of Life and its association with anemia in Al-Gharbiyah Governorate, Egypt" who found that, most of patients were aged between 50 to 60 years and male to female ratio are almost equal. Also the total score of impairment of quality of life was slightly higher among urban than rural.

Our findings about gender are also similar to those reported by Parakash et al., (2012) in study about " Frequency of poor quality of life and predictors of health related quality of life in cirrhosis at a tertiary care hospital Pakistan" who also found that mean quality of life score is not significantly different among different age groups.

Results of the current study showed that regarding group 1 more than half had satisfactory knowledge score, versus less than quarter of group 2 That high statistically significant difference. This may be attributed to theoretical sessions that were provided to group1 which cover all aspects of chronic hepatitis.

This no associated with Hamza et al., (2015) who found less than three quarter and slight than three quarter of both groups were having an unsatisfactory knowledge score levels. This finding could be attributed to lack of patient's education about liver cirrhosis because the majority of both groups were illiterate.

In the present study it shows that there were significant negative correlations between score of knowledge with "Emotional Function" and "Worry". This supported with Hamza et al., (2015) in study about "Impact of Designed Nursing Intervention Protocol on quality of life for liver cirrhosis patients in Minia University Hospital" revealed that most of the quality of life domains (Activity, Emotional, and worry) mean scores for the study group were high. This was agreed with that of Sharif et al., (2005) who found that, besides receiving knowledge and information about disease to keep their good quality of life and relief their anxiety and long term behavioral, attitude changes need to take place which can occur only over a longer period of time.

\section{Conclusion}

The study concluded that Patient's knowledge regarding chronic hepatitis is satisfactory in group 1 , while there is unsatisfactory knowledge in group 2. Negative correlation between grade of knowledge and quality of life domains in group1.

\section{Recommendations}

Based on the previous findings of the present study, the following recommendations are suggested:

- Providing educational programs to improve elderly knowledge about chronic hepatitis and early detection especially high risk group.

- Follow up for elderly patient with chronic hepatitis to minimize its complication. Encourage elderly people to modifying their behavior and taking active role in preventing exposure to infection transmission to reduce the burden on health related quality of life.

- Furthermore research among elderly patient with chronic hepatitis for quality of life and knowledge.

\section{References}

1. Alghazaly G., Abd El Raouf Y., \& Zaglol K., (2016): Impact of chronic liver disease on Health Related Quality of Life and its 
association with anemia in Al-Gharbiyah Governorate, Egypt. Global Advanced Research Journal of Medicine and Medical Sciences Vol. 5.No. 2. pp. 053-066.

2. Clements A., \& Greenslade L., (2013): Liver disease 1: Nursing care for end-stage liver disease. Royal College of Nursing (RCN), Liver disease Role in Disease and Injury Prevention, journal of Nursing Times; Vol.110.No. 29.pp1619.

3. Dooley J., (2011): Sherlock's Diseases of the Liver and Biliary System. Journal of Medical science, Vol. 33. No 10. pp: 335-340.

4. Dusan D., Nada V., Darija B., Goran Z., Tamara M., Milan M., Miodrag N., Rada S., Zobair M., \& Tatjana D., (2013): Validation of the chronic liver disease questionnaire in Serbian patients, World Journal Gastroenterol (WJG) Vol. 14.No. 19..pp:4950-4957.

5. Gao R., Gao F., Li G., \& Hao J., (2013): Health-related quality of life in Chinese patients with chronic liver disease. Health Quality of Life Outcomes. Journal of Hepatology Vol.3.No. 4. pp. 233-237.

6. Hamza S., Yousef W., Sayed F., Mahmoud S., \& Mohamed L., (2015): Impact of Designed Nursing Intervention Protocol on quality of life for liver cirrhosis patients in Minia University Hospital. Medical - Surgical Nursing. International Organization of Scientific Research (IOSR)- Journal of Nursing and Health Science (IOSR-JNHS) Vol. 4, No.4. pp: 07-15. Available at; www.iosrjournals.org.

7. Kandeel A., Genedy M., El-Refai S., Lfunk A., Fontanet A., \& Talaat M., (2015): the prevalence of hepatitis $\mathrm{C}$ virus infection in Egypt 2015: implication for future policy on prevention and treatment. Journal of liver international Vol. 37 pp: 45-53.

8. Lam C., Lai C., Yuen M., \& Fong D., (2009): Psychometrics of the chronic liver disease questionnaire for Southern Chinese patients with chronic hepatitis B virus infection. World Journal Gastroenterol; Vol. 15 No. 26. PP 3288-3297.

9. Matsushita H., Ikeda F., \& Iwasaki Y., (2014): Assessment of health-related quality of life and how it predicts the outcome of pegylated interferon and ribavirin therapy for chronic hepatitis Clinical Journal of Gastroenterology Hepatol; Vol.29. No. 2 . pp:337-43.

10. Mühlberger N., Schwarzer R., Lettmeier B., Sroczynski

Zeuzem S., \& Siebert U., (2009): HCV-related burden of disease in
Europe: a systematic assessment of incidence, prevalence,

morbidity, and mortality. Bio Med Central, BMC Public Health Journal; Vol. 9.No. 34. pp:1-14.

11. Parakash O., Romaina I., Fatima J., Iqbal A., and Wasim J., (2012): Frequency of poor quality of life and predictors of health related quality of life in cirrhosis at a tertiary care hospital Pakistan; Journal of BioMed Central (BMC) research notes; Vol 5.No.446 .pp: 1-8.

12. Pashaee F., Taleghani F., Tavakol K., \& Rezae A., (2010): Family experiences from care giving of patient with coronary artery bypass graft surgery: a qualitative study. International Journal of Nursing Research;Vol 5.No. 16. pp :61-71.

13. Rahimi R., \& Rockey D., (2011): Complications and outcomes in chronic liver disease. Journal of Gastroenterol, Vol. 27.No.3. pp.204-209.

14. Scottish Public Health Observatory Report on Chronic Liver Disease, (2012): chronicliver-disease key-points, $7^{\text {th }}$ ed, Mosby Elsevier, Canada, pp:1009 - 1011. Available at: www.scotpho.org.uk/health-wellbeing-anddisease/chronic-liver-disease/key-points.

15. Sharif F., Mohebbi S., Tabatabaee H., Saberi M., \& Gholamzadeh S., (2005): Effects of psycho-educational intervention on healthrelated quality of life (QOL) of patients with chronic liver disease referring to Shiraz University of Medical Sciences Health and quality outcomes journal. Vol. 26. No.11.pp: 1702-1708.

16. Singh A., \& pandey B., (2014): intelligent technique and applications in liver disorders: A survey International Journal of Biomedical; Vol 16 No 1.Pp27-70.1

17. Ware J., \& Sherbourne C., (2009): The most 36-item short-form health survey (SF-36). I. Conceptual framework and item selection. Medical Care Journal; Vol. 30. No. 6. pp: 473483.

18. World health organization (WHO), (2012): Health education; theoretical concept, effective strategies and core competencies. A foundation document to guide capacity development of health educators, pp.1-60. Available at: http://applications.emro.who.int/dsaf/EMRPUB 2012 EN 1362.pdf.

19. World Health Organization (WHO), (2015): World Hepatitis Day 2015: Prevent hepatitis, available at: www.who.int/topic/hepatitis. 